УДК 343.13:98

DOI 10.18413/2712-746X-2020-44-3-516-526

\title{
Сравнительно-правовой анализ нормативных актов, регламентирующих производство судебной экспертизы и процессуальный статус сведущих лиц в уголовном процессе России и Германии
}

\author{
1)Лукичев Б.А., ${ }^{2)}$ Алексеев С.Г. \\ 1)Урало-Сибирская коллегия адвокатов, \\ Россия, 620026, Екатеринбург, ул. Тверитина, 34/9 \\ E-mail: lukichev_b@mail.ru \\ 2)Уральский научно-исследовательский институт \\ Всероссийского добровольного пожарного общества, \\ Россия, 620137, Екатеринбург, ул. Учителей, 32, офис 407 \\ E-mail: 3608113@mail.ru
}

\begin{abstract}
Аннотация. Современный тип немецкого уголовного процесса является наиболее ярким представителем романо-германской правовой системы и поэтому служит объектом сравнения с уголовным судопроизводством других стран. Вместе с тем вопросы применения сведущими лицами специальных знаний в уголовном процессе России и Германии изучены недостаточно. В связи с этим авторы провели сравнительно-правовой анализ норм уголовно-процессуального законодательства России и Германии, регламентирующих производство судебной экспертизы. В результате выявлены общие и отличительные свойства, степень сходства и различия юридических терминов, используемых в отношении указанных лиц в нормативно-правовых актах сопоставляемых правовых систем. Ключевой фигурой в уголовном процессе Германии является суд, который несет бремя доказывания, совмещая функции обвинения и разрешения дела по существу. Сведущие лица в качестве самостоятельных участников уголовного судопроизводства не рассматриваются, поскольку являются «средствами судебного доказывания». Результаты исследования позволяют по-новому взглянуть на отечественный институт сведущих лиц, а также расширить представление о применении специальных знаний в уголовном процессе Федеративной Республики Германия и государств, следующих в «кильватере» немецкого Strafprozess.
\end{abstract}

Ключевые слова: уголовное судопроизводство, специалист, эксперт, прокуратура, суд.

Для цитирования: Лукичев Б.А., Алексеев С. Г. 2020. Сравнительно-правовой анализ нормативных актов, регламентирующих производство судебной экспертизы и процессуальный статус сведущих лиц в уголовном процессе России и Германии. NOMOTHETIKA: Философия. Социология. Право. 45 (3): 516-526. DOI 10.18413/2712-746X-2020-44-3-516-526

\section{Comparative legal analysis of regulations governing the production of forensic examination and procedural status of expert witnesses in the criminal process in Russia and Germany}

\author{
${ }^{1)}$ Boris A. Lukichev, ${ }^{2}$ Sergey G. Alexeev \\ 1)Ural-Siberian Bar Association, \\ 34/9 Tveritina St, Yekaterinburg, 620026, Russia \\ E-mail: lukichev_b@mail.ru \\ ${ }^{2)}$ Ural Research Institute of the All-Russian Voluntary Fire Society, \\ 32-407 Uchiteley St, Yekaterinburg, 620002, Russia \\ E-mail: 3608113@mail.ru
}

Abstract. The modern type of German criminal procedure is the most prominent representative of the
Romano-Germanic legal system and therefore serves as an object of comparison with the criminal
procedure of other countries. At the same time, the issues of the use of special knowledge by 
knowledgeable persons in the criminal proceedings of Russia and Germany have not been sufficiently studied. In this regard, the authors conducted a comparative legal analysis of the norms of the criminal procedural legislation of Russia and Germany, regulating the production of forensic examination. As a result of this study, the general and distinctive properties, the degree of similarity and differences in legal terms used in relation to these persons in the regulatory legal acts of the compared legal systems were revealed. The key figure in German criminal proceedings is the court, which bears the burden of proof, combining the functions of the prosecution and the resolution of the case on the merits. Knowledgeable persons as independent participants in criminal proceedings are not considered, since they are "means of judicial evidence". The German legislator, unlike the Russian one, does not seek to specify the procedural status of competent persons in criminal proceedings at the level of the CPC of Germany, does not detail the procedure for the appointment and production of a forensic examination, as well as the timelines for its production and the requirements that determine the mandatory nature of its appointment. The results of the study allow us to take a fresh look at the domestic institution of knowledgeable persons, as well as expand the understanding of the application of special knowledge in the criminal process of the Federal Republic of Germany and the states following in the "wake” of the German Strafprozess.

Keywords: criminal proceedings, expert witness, prosecutor's office, court.

For citation: Lukichev B.A., Alexeev S.G. 2020. Comparative legal analysis of regulations governing the production of forensic examination and procedural status of expert witnesses in the criminal process in Russia and Germany. NOMOTHETIKA: Philosophy. Sociology. Law series. 45 (3): 516-526 (in Russian). DOI 10.18413/2712-746X-2020-44-3-516-526

\section{Введение}

Современный тип немецкого уголовного процесса является наиболее ярким представителем романо-германской правовой системы. К странам, уголовное судопроизводство которых исторически аналогично немецкому, традиционно относят Австрийскую и Венгерскую республики, Норвегию и Швейцарскую Конфедерацию, поэтому нередко он служит объектом сравнения с уголовным процессом других стран. Отсюда и несомненный интерес к современному немецкому уголовному процессу, который проявляется как в нашей стране, так и за рубежом [Филимонов, 1994; Калиновский, 2000; Смирнов, 2001; Гришай, 2003; Ларичев, 2004; Стойко 2006; Трефилов, 2011; Головенков и др., 2012; Виноградов, 2014; Брестер и др., 2015; Германо-Российская ассоциация ..., 2015, 2017; Потёмкин, 2015; Коновалов, 2017, 2018; Луцик и др., 2018; Шевцова, 2018; Bošković et al, 2018; Kirchhofer, 2017].

Вопрос о применении сведущими лицами специальных знаний в уголовном процессе России и Германии в той или иной мере уже рассматривался российскими исследователями [Глотов, 1978; Бутов, 2009; Латыпов, 2015; Иванова, 2017; Кащенко, 2019; и др.], но, тем не менее, целостного восприятия по данной проблематике пока не наблюдается. Именно поэтому нам представляется возможным предложить свое видение этого вопроса.

\section{Нормативные акты, регламентирующие производство судебной экспертизы в уголовном процессе России и Германии}

Порядок назначения и производства судебной экспертизы, а также процессуальный статус сведущих лиц в уголовном процессе Российской Федерации и Федеративной Республики Германия регламентируется в уголовно-процессуальных кодексах указанных стран. В России производство судебной экспертизы регламентируется также и другими нормативными актами. Например, Федеральным законом РФ от 31 мая 2001 г. № 73-Ф3 «О государственной судебно-экспертной деятельности в Российской Федерации», Постановлением Пленума Верховного Суда РФ от 21 декабря 2010 г. № 28 «О судебной экспертизе по уголовным делам», ведомственными инструкциями. 
В Германии производство судебной экспертизы регламентируется УПК ФРГ [Филимонов, 1994; Трефилов, 2011; Головенков и др., 2012], специальными служебноправовыми предписаниями (абз. 2 § 76) и региональными нормативно-правовыми актами (Bundesministerin der Justiz und für Verbraucherschutz).

Уголовно-процессуальный кодекс ФРГ (далее - УПК ФРГ) является основным законодательным актом, регламентирующим немецкий уголовный процесс. Он был принят 1 февраля 1877 года и с тех пор претерпел множество изменений. В настоящее время УПК ФРГ действует в редакции от 7 апреля 1987 года, с дополнениями, внесенными Законами ФРГ 11 марта 2008 года [Головенков и др., 2012] и 17 августа 2017 года ${ }^{1}$. Кодекс содержит 8 частей (названных в законе книгами), 37 разделов и порядка 637 параграфов.

Уголовно-процессуальный кодекс Российской Федерации (далее - УПК РФ) принят Государственной Думой Федерального собрания Российской Федерации 22 ноября 2001 года. Структура Кодекса состоит из 6 частей, 19 разделов, 59 глав и 548 статей. К настоящему времени в УПК РФ внесено изменений и дополнений порядка 280 раз, что также свидетельствует об активном совершенствовании уголовно-процессуального законодательства России.

\section{Сведущие лица в уголовном процессе России и Германии}

В качестве сведущих лиц, т.е. лиц, обладающих специальными знаниями, УПК РФ определяет эксперта и специалиста, тогда как УПК ФРГ - эксперта (Sachverständigen) и сведущего свидетеля (Sachverständige Zeugen).

Российское уголовно-процессуальное законодательство относит эксперта и специалиста к лицам, принимающим участие в уголовном процессе, и классифицирует их в качестве «иных участников уголовного судопроизводства» (гл. 8), т.е. лиц, выполняющих функцию содействия правосудию. По УПК ФРГ эксперты и свидетели в качестве самостоятельных участников уголовного судопроизводства не рассматриваются, поскольку, согласно теории немецкого уголовного процесса, являются «средствами судебного доказывания» [Луцик и др., 2018, с. 110]. Суд, в соответствии с требованиями УПК ФРГ, обязан устанавливать истину, исследуя все обстоятельства дела, независимо от представленных доказательств и заявленных ходатайств участников процесса (§ 33, 33a, абз. 2 § 244, абз. 2 § 245). Исходя из этого, отдельные российские процессуалисты относят современный уголовный процесс Германии к «национальному» либо «смешанному» типу, так как с точки зрения «идеальной» типологии немецкий уголовный процесс не является в чистом виде розыскным или состязательным [Латыпов, 2015, с. 23; Калиновский, 2000, с. 3].

Согласно УПК РФ, специалист - это лицо, обладающее специальными знаниями. Он привлекается к участию в процессуальных действиях для содействия в обнаружении, закреплении и изъятии предметов и документов, применении технических средств в исследовании материалов уголовного дела, для постановки вопросов эксперту, а также для разъяснения сторонам и суду вопросов, входящих в его профессиональную компетенцию (ч. 1 ст. 58, ч. 1 ст. 144). Права и обязанности специалиста закреплены в ч. 3 и 4 ст. 58 УПК РФ.

В УПК ФРГ понятия «специалист» нет, но существует категория лиц, которые именуются как Sachverständige Zeugen - сведущий свидетель. Этой процессуальной фигуре в УПК ФРГ посвящен только один параграф, согласно которому сведущий свидетель -

${ }^{1}$ Gesetz zur effektiveren und praxistauglicheren Ausgestaltung des Strafverfahrens. 2017. Das Bundesgesetzblatt im Internet. URL: https://www.bgbl.de/xaver/bgbl/start.xav?startbk=Bundesanzeiger _BGBl\&jumpTo=bgbl117s3202.pdf\#_bgbl_\%2F\%2F*\%5B\%40attr_id\%3D\%27bgbl117s3202.pdf\%2 7\%5D_1564111075756 (дата обращения: 02.03.2020); Strafprozeßordnung. URL: https://www.gesetze-im-internet.de/stpo/index.html (дата обращения: 02.03.2020). 
это лицо, обладающее специальными познаниями. Он допускается в процесс для дачи показаний и может быть допрошен по правилам, установленным для допроса свидетелей (§ 85), что, собственно, и относит его к категории свидетеля.

Процессуальное положение сведущего свидетеля регламентируется разд. 6 части 1 УПК ФРГ, устанавливающей права и обязанности свидетеля в уголовном процессе. В силу своих профессиональных знаний сведущий свидетель по сути достаточно близок к определению понятия «специалист», которое дано в ч. 4 ст. 80 УПК РФ. Комментарий к $\S 85$ УПК ФРГ указывает, что свидетели, обладающие специальными познаниями, отличаются от экспертов тем, что они без поручения со стороны суда дают показания о своем восприятии фактов на основании специальных знаний [Головенков и др., 2012, с. 136]. При допросе сведущий свидетель способен не только сообщить суду фактическую информацию по делу, но и указать причины и последствия конкретного происшествия, поскольку для этого он использует знания, лежащие в основе его профессиональной деятельности. Например, «семейный» врач может квалифицированно изложить ход лечения своего пациента, течение болезни и ее проявления; ветеринар - предполагаемые причины наблюдаемой им массовой гибели скота; инспектор дорожной полиции - обстоятельства дорожно-транспортного происшествия, административное расследование которого он проводил [Бутов, 2009, с. 53]; пожарный инспектор - причины пожара, если он осуществлял исследование места пожара по долгу службы и т.п.

Согласно УПК РФ, эксперт - это лицо, обладающее специальными знаниями, назначенное в порядке, установленном законом, для производства судебной экспертизы и дачи заключения (ч. 1 ст. 57). Тогда как по УПК ФРГ эксперт - это официально назначенное или уполномоченное лицо, которое по роду своей профессиональной деятельности занимается наукой, искусством или ремеслом, знание в которых является предпосылкой для дачи заключения (абз. $1 \S 75)$. Кроме того, экспертное заключение обязан также дать тот, кто объявил свою готовность перед судом (абз. 2 § 75).

\section{Применение специальных знаний в уголовном процессе России и Германии}

Порядок назначения и производства судебной экспертизы, а также процессуальный статус экспертов в уголовных процессах России и Германии во многом схожи, но не тождественны, например:

- УПК РФ содержит требования, определяющие обязательность назначения и производства судебной экспертизы (ст. 196 УПК), в то время как УПК ФРГ таких требований не имеет;

- правом назначения судебной экспертизы по УПК РФ наделены дознаватель, орган дознания, следователь, руководитель следственного органа, суд (ч. 1 ст. 144, ч. 1 ст. 283). Тогда как по УПК ФРГ выбор привлекаемых по делу экспертов и определение их числа осуществляет судья (абз. 1 § 73, 162, 165, 169);

- УПК РФ допускает назначение и производство судебной экспертизы на стадии возбуждения уголовного дела (ч. 4 ст. 195 УПК), тогда как УПК ФРГ - на стадии предварительного расследования (§§ 162, 165, 169);

- судебно-экспертная деятельность в России осуществляется на принципе независимости судебного эксперта (ст. 4 ФЗ РФ № 73-Ф3), в то время как УПК ФРГ определяет, что судья вправе руководить деятельностью эксперта настолько, насколько это ему представляется необходимым (§ 78). Вместе с тем, комментарий к данному параграфу указывает, что данное положение не распространяется на профессиональную сферу деятельности эксперта, а руководство судьи заключается в точной формулировке поручений, предоставлении материалов дела и юридической информированности [Головенков и др., 2012, с. 124]; 
- сроки производства судебной экспертизы в российском уголовном процессе определены в ведомственных инструкциях, в то время как УПК ФРГ обязывает судью обсуждать сроки представления экспертного заключения с судебным экспертом (абз. 1 § 73). Договоренность заключается, как правило, устно, а согласованный срок вносится в материалы дела [Головенков и др., с. 122]. Вместе с тем Кодекс допускает возможность прокуратуры заключить с экспертом договоренность о даче предварительного заключения и требовать от последнего представление экспертного заключения (абз. 1 § 161a). Но это, как представляется нам, возможно лишь в том случае, если на стадии предварительного расследования заслушивание эксперта будет осуществляться судьей по ходатайству прокуратуры либо проводиться прокуратурой по поручению судьи;

- по УПК РФ судебная экспертиза производится государственными судебными экспертами и иными экспертами из числа лиц, обладающих специальными знаниями (ч. 2 ст. 195). Привлечение иных экспертов к производству судебной экспертизы достаточно полно рассмотрено в Постановлении Пленума Верховного Суда РФ от 21 декабря 2010 г. № 28. Тогда как по требованиям УПК ФРГ производство судебных экспертиз должно проводиться, как правило, государственными экспертами. Это положение вытекает из УПК ФРГ, который гласит: экспертиза проводится лицами, которые состоят на государственной службе. Другие лица могут быть назначены только в случае, если этого требуют особые обстоятельства (абз. 2 § 73). Особые обстоятельства могут заключаться в том, что государственный эксперт временно не имеет возможности для подготовки заключения или необходим эксперт с более высокой или специальной квалификацией (комментарий к абз. 2 § 73) [Головенков и др., с. 122]. Например, экспертное заключение могут дать уполномоченные на то профессора государственных университетов, имеющие статус чиновника, даже если они уже вышли в отставку, доценты государственных университетов, не имеющие статуса чиновника, и апробированные врачи (комментарий к абз. 1 § 75) [Головенков и др., с. 123]. В особо важных случаях экспертное заключение может быть поручено профильным ведомствам (абз. 3 § 83);

- российский уголовный процесс не детализирует участие эксперта в процессуальных действиях. Согласно УПК РФ, эксперт вправе участвовать с разрешения лица, ведущего производство по уголовному делу, в процессуальных действиях и задавать вопросы, относящиеся к предмету судебной экспертизы (п. 3 ч. 3 ст. 57). Тогда как по УПК ФРГ эксперт вправе знакомиться с материалами дела, присутствовать при допросе свидетелей или обвиняемых и задавать им вопросы (абз. 2 §0), принимать участие в проводимых судьей осмотрах (абз. 2 § 168d);

- УПК РФ наделяет эксперта правом ходатайствовать о предоставлении ему дополнительных материалов, необходимых для дачи заключения, либо о привлечении к производству судебной экспертизы других экспертов (п. 2 ч. 3 ст. 57), тогда как по УПК ФРГ эксперт вправе требовать предоставление дополнительных сведений, полученных путем допроса свидетелей или обвиняемых (абз. 1 § 80);

- УПК РФ содержит перечень определенного рода действий, которые эксперт не вправе осуществлять самостоятельно без разрешения либо согласования с лицом, ведущим производство по уголовному делу (ч. 4 ст. 57), тогда как УПК ФРГ не содержит подобного рода запретов;

- в УПК РФ порядок назначения и производства судебной экспертизы, а также структура постановления о ее назначении определены в ч. 1 ст. 195, структура заключения эксперта - в ч. 1 ст. 204 Кодекса. Кроме того, все указанное выше детально определено в Федеральном законе РФ № 73-Ф3 «О государственной судебно-экспертной деятельности в Российской Федерации», тогда как уголовно-процессуальное законодательство Германии не детализирует процедуру назначения и производства судебной экспер- 
тизы, что так же относится и к структуре постановления о назначении судебной экспертизы и заключения эксперта;

- УПК РФ разрешает в процессе расследования по уголовному делу назначение и производство комиссионной, комплексной, дополнительной и повторной судебных экспертиз (ч. 1 ст. 200, ч. 1 ст. 201, ч. 1 и 2 ст. 207). Производство дополнительной или повторной экспертизы может быть назначено при наличии противоречий между заключениями экспертов, которые невозможно преодолеть в судебном разбирательстве путем допроса экспертов (ч. 1.2 ст. 144, ч. 4 ст. 283). Тогда как немецкое уголовно-процессуальное законодательство предусматривает назначение только «новой экспертизы» с участием того же или другого (других) экспертов (§ 83 УПК ФРГ). Новая экспертиза может быть назначена, если экспертное заключение будет признано неудовлетворительным по следующим основаниям: 1) существуют сомнения в компетентности эксперта и в установленных в экспертном заключении фактах; 2) заключение противоречиво или неясно; 3) в основу экспертного заключения были положены не соответствующие действительности фактические предпосылки; 4) экспертное заключение содержит противоречия; 5) новый эксперт располагает научно-исследовательскими средствами, которые значительно превосходят средства прежнего эксперта (предл. 2, абз. 4 § 244). Вместе с тем содержание указанных параграфов позволяет сделать вывод, что экспертизы могут быть как единоличные, так и комиссионные, комплексные, дополнительные и повторные, но данных терминов УПК ФРГ не использует;

- УПК РФ определяет, что заключение эксперта должно быть составлено в письменном виде и содержать исследования и выводы по вопросам, поставленным перед экспертом лицом, ведущим производство по уголовному делу, или сторонами (ч. 1 ст. 80). Тогда как УПК ФРГ допускает, что на стадии предварительного расследования, в зависимости от предписания судьи, эксперт обязан представить заключение в письменной или устной форме (§ 82);

- в соответствии с требованиями УПК РФ решение об отводе эксперта и специалиста в ходе досудебного производства по уголовному делу принимается дознавателем, следователем, а также судом в порядке, установленном ч. 1 ст. 69 УПК РФ. В ходе судебного производства указанное решение принимает суд, рассматривающий данное уголовное дело, или судья, председательствующий в суде с участием присяжных заседателей (ст. 70, 71). Обстоятельства, исключающие участие эксперта и специалиста в производстве по уголовному делу, а также их обязанность устраниться от участия в судопроизводстве, определены в ст. 61, ч. 1 ст. 62, ч. 2 ст. 70 УПК РФ. Заявлять отвод эксперту и специалисту имеют право подозреваемый, обвиняемый, защитник, потерпевший, свидетель, гражданский истец и гражданский ответчик (п. 5 ч. 2 ст. 42, п. 4 ч. 4 ст. 44, п. 5 ч. 4 ст. 46, п. 5 ч. 4 ст. 47 , п. 8 ч. 1 ст. 53, п. 8 ч. 2 ст. 54, п. 2 ч. 1 ст. 198). Тогда как по УПК ФРГ решение об отводе эксперта при производстве по делу принимает суд. Ходатайствовать об отводе эксперта имеют право прокурор, частный обвинитель и обвиняемый. Для этого они должны поименно назвать тех экспертов, участие которых в деле для них нежелательно (абз. 2 § 74). Ходатайство в суд об отводе должно быть оформлено заявлением (§ 26). Основанием для отвода эксперта не может служить то обстоятельство, что ранее он был допрошен в качестве свидетеля (абз. 1 § 74). Порядок отвода сведущего свидетеля УПК ФРГ не содержит;

- в УПК РФ указано, что лицо, ведущее производство по делу, вправе по собственной инициативе либо по ходатайству сторон допросить эксперта для разъяснения или дополнения данного им ранее заключения (ч. 1 ст. 205, ч. 1 ст. 282). Порядок допроса эксперта, в соответствии с указанными статьями УПК РФ, содержит свою особую регламентацию. Тогда как по УПК ФРГ руководство рассмотрением дела, а также инициатива ведения судебного следствия, включая допрос лиц, участвующих в деле, принадлежит 
единолично председательствующему коллегиального суда (абз. 1 § 238). И только с его разрешения судьи и шеффены, прокурор и защитник могут задавать вопросы и допрашивать экспертов. Такой допрос считается составной частью заключения эксперта. Сведения, сообщаемые им при производстве допроса, заносятся в протокол секретарем суда, а если заключение излагается в отдельном документе, он прилагается к протоколу судебного заседания [Бутов, 2009, с. 54]. Перекрестный допрос эксперта является исключением из этого правила. Например, если эксперт вызван в суд по ходатайству прокуратуры, председательствующий суда предоставляет право проводить допрос эксперта чиновнику прокуратуры и лишь потом защитнику. Эксперт, вызванный подсудимым, допрашивается защитником и лишь потом чиновником прокуратуры (абз. 1 § 239). Если чиновник прокуратуры или защитник станут злоупотреблять этим правом, то председательствующий может не только отклонить вопросы, не относящиеся к делу, но и лишить указанных лиц права проводить допрос (§ 240). Председательствующий, после производства допроса чиновником прокуратуры и защитником, также должен задать эксперту вопросы, являющиеся необходимыми для выяснения обстоятельств дела (абз. 2 § 239);

- меры юридической ответственности в уголовно-процессуальном законодательстве России и Германии, налагаемые на эксперта, существенно отличаются друг от друга. Например, УПК ФРГ предусматривает, что если эксперт необоснованно откажется от дачи заключения, то на него может быть наложен денежный штраф, а также возложена обязанность по возмещению причиненных убытков. В случае повторного отказа такой штраф может быть наложен повторно. Это же правило действует и в случае если эксперт, обязанный представить заключение, откажется обсуждать предусмотренный в абз. 1 § 73 УПК ФРГ срок представления заключения или пропустит этот срок. Наложению денежного штрафа должно предшествовать установление дополнительного срока представления заключения. В случае повторного пропуска срока денежный штраф может быть наложен еще раз (§ 77). При неявке эксперта в прокуратуру по повестке или его отказе без уважительной причины давать показания и представлять экспертное заключение прокуратура вправе применить меры принуждения, предусмотренные $\S \S 51,70$ и 77 (абз. $2 \S 161$ ). Кроме того, в отношении эксперта также могут применяться предписания разд. 6 части 1 УПК ФРГ о свидетелях (§ 72), предусматривающие уголовно-правовые последствия за ложные или неполные показания (§ 57). Тогда как УПК РФ устанавливает, что эксперт несет уголовно-правовую ответственность за дачу заведомо ложного заключения и за разглашение данных предварительного расследования (ч. 5 и 6 ст. 57). Других мер ответственности или принуждения УПК РФ не содержит;

- заключение и показания эксперта и специалиста, согласно УПК РФ, являются самостоятельными видами доказательств по уголовному делу (п. 3 и 3.1 ч. 2 ст. 74), тогда как в УПК ФРГ перечень доказательств по уголовному делу не приведен.

Заключение и показания эксперта и специалиста не являются незыблемым доказательством для суда и органов досудебного производства. Никакие доказательства, согласно УПК РФ, не имеют заранее установленной силы (ч. 2 ст. 17). Судья, присяжные заседатели, а также прокурор, следователь, дознаватель оценивают доказательства по своему внутреннему убеждению, основанному на совокупности имеющихся в уголовном деле доказательств, руководствуясь при этом законом и совестью (ч. 1 ст. 17). В целом эти положения очень близки требованиям УПК ФРГ. Например, согласно § 261 УПК ФРГ суд оценивает доказательства по своему свободному убеждению, сложившемуся на основании рассмотрения всех обстоятельств дела в их совокупности.

\section{Заключение}

Таким образом, следует отметить, что в современных уголовных процессах России и Германии имеется много общих черт. Обусловлено это тем, что в историческом прошлом на российскую правовую систему значительное влияние оказывала романо- 
германская система права. Но в уголовных процессах двух стран имеются и существенные отличия. Например, в теории и практике немецкого уголовного процесса понятие сторон и принцип состязательности отвергаются. Сведущие лица в качестве самостоятельных участников уголовного судопроизводства не рассматриваются, поскольку являются «средствами судебного доказывания». Порядок назначения и производства судебной экспертизы, а также процессуальный статус экспертов в уголовном процессе России и Германии во многом схожи, но нетождественны. Немецкий законодатель, в отличие от российского, не стремится на уровне УПК ФРГ конкретизировать процессуальный статус сведущих лиц в уголовном процессе, не детализирует процедуру назначения и производства судебной экспертизы, а также сроки ее производства и требований, определяющих обязательность ее назначения. Не разграничивает судебные экспертизы на единоличные, комиссионные, комплексные, дополнительные или повторные. Ключевой фигурой в уголовном процессе Германии является суд, который несет бремя доказывания и установления истины по делу, совмещая функции обвинения и разрешения дела по существу.

Проведенный сравнительно-правовой анализ нормативных актов, регламентирующих производство судебной экспертизы в уголовном процессе России и Германии, позволяет по-новому взглянуть на отечественный институт сведущих лиц, а также расширить наше представление о применении специальных знаний в уголовном процессе Федеративной Республики Германия и государств, следующих в «кильватере» немецкого Strafprozess.

\section{Список источников}

1. Gesetz zur effektiveren und praxistauglicheren Ausgestaltung des Strafverfahrens. 2017. Das Bundesgesetzblatt im Internet. URL: https://www.bgbl.de/xaver/bgbl/start.xav ?startbk=Bundesanzeiger _BGBl\&jumpTo=bgbl117s3202.pdf\#_bgbl_\%2F\%2F*\%5B\%40attr_id\%3D\%27bgbl117s3202.pdf\%2 7\%5D_1564111075756 (дата обращения: 02.03.2020).

2. Strafprozeßordnung. URL: https://www.gesetze-im-internet.de/stpo/index.html (дата обращения: 02.03.2020).

\section{Список литературы}

1. Брестер А.А., Быковская А.С. 2015. Сравнительно-правовой анализ упрощенного производства в уголовном процессе России и Германии. Актуальные проблемы российского права, 12 (61): 162-170.

2. Бутов В.Н. 2009 г. Эксперт в зарубежном (континентальном) уголовном процессе. В кн.: Материалы 2-й Международной научно-практической конференции «Теория и практика судебной экспертизы в современных условиях». М., Проспект: 53-55.

3. Виноградов А.С. 2014. Система досудебного производства в уголовном процессе России и Германии. Журнал правовых и экономических исследований, (3): 32-35.

4. Глотов О.М. 1978. Экспертиза в современном уголовном процессе ФРГ. Известия высших учебных заведений. Правоведение, (4): 68-74.

5. Головенков П., Понятовская Т. 2015. Уголовно-правовой институт конфискации имущества в Германии и России: сущность, виды и проблемы применения. В кн.: ГерманоРоссийская ассоциация юристов. Сборник статей о праве Германии. Hamburg, Deutsch-Russische Juristenvereinigung e.V., (1): 324-339.

6. Головенков П., Спица Н. 2012. Уголовно-процессуальный кодекс Федеративной Республики Германия - Strafprozessordnung (StPO) - Научно-практический комментарий и перевод текста закона со вступительной статьёй профессора Хелльманна «Введение в уголовнопроцессуальное право ФРГ». Потсдам, Университетское Издательство Потсдама, 404 с.

7. Гришай И.Б. 2003. Досудебное производство в уголовном процессе Германии и России (сравнительно-правовой анализ): Автореф. дис. ... канд. юрид. наук. СПб., 19 с.

8. Дерра М. 2015. Сделка со следствием в уголовном процессе. В кн.: ГерманоРоссийская ассоциация юристов, Сборник статей о праве Германии. Hamburg, Deutsch-Russische Juristenvereinigung e.V., 2017, (2): 284-295. 
9. Иванова А.В. 2017. Сравнение производства судебной экспертизы по уголовным делам в Российской Федерации и Федеративной Республике Германия. Международное уголовное право и международная юстиция, (1): 29-32.

10. Калиновский К.Б. 2000. Уголовный процесс современных зарубежных государств. Петрозаводск, изд-во Петрозаводского госуниверситета, 48 с.

11. Кащенко С.Г. 2019. Правовой статус экспертов в современном германском уголовнопроцессуальном праве. В кн.: Материалы V Международной научно-практической конференции «Уголовное производство: процессуальная теория и криминалистическая практика». СимферопольАлушта, изд-во Крымского федерального университета имени В.И. Вернадского, 43-45.

12. Коновалов С.Г. 2017. Германский «следственный судья» в зеркале российской уголовно-процессуальной науки: факты и мифы. Закон, (1): 170-181.

13. Коновалов С.Г. 2018. Элементы германской модели досудебного производства в уголовном процессе постсоветских государств: Автореферат дис. ... канд. юрид. наук. М., 22 с.

14. Ларичев В.В. 2004. Предварительное расследование преступлений в США и Германии: Автореферат дис. .... канд. юрид. наук. М., 24 с.

15. Латыпов В.С. 2015. К вопросу о процессуальном статусе «иных участников уголовного судопроизводства» в законодательстве Германии. Международное уголовное право и международная юстиция, (3): 22-25.

16. Луцик В.В., Войнарович А.Б., Савченко В.А., Садовая Т.В., Самарин В.И., Трефилов А.А., Юрчишин Д.В. 2018. Уголовный процесс европейских государств. М., Проспект, 100-150.

17. Потёмкин И.Ю. 2015. Цели доказывания в системе принципов уголовного процесса России и Германии: сравнительно-правовой анализ. Вестник Северо-Восточного государственного университета, (23): 71-76.

18. Смирнов А.В. 2001. Состязательный процесс. СПб., Альфа, 320 с.

19. Стойко Н.Г. 2006. Уголовный процесс западных государств и России: сравнительное теоретико-правое исследование англо-американской и романо-германской правовых систем. СПб., СПбГУ, 264 с.

20. Трефилов А.А. 2011. Система УПК ФРГ с приложением в виде перевода УПК ФРГ на русский язык. М., МГУ, 421 с.

21. Филимонов Б.А. 1994. Федеративная Республика Германия. Уголовнопроцессуальный кодекс. М., Манускрипт, 204 с.

22. Шевцова Л.В. 2018. К вопросу о соотношении уголовного преследования участников преступных организаций в России и странах романо-германской системы права. Современный юрист, (1): 75-81.

23. Bošković A., Radović N. 2018. Comparative overview of the preliminary proceedings in the Republic of Serbia, Germany, and Italy. International Journal of Law, Crime and Justice. 52 (March): 47-57.

24. Kirchhofer S. 2017. Die Untersuchungshaft in Südamerika und Deutschland. Eine rechtsvergleichende Analyse. Wiesbaden, Springer Fachmedien, 273 c.

\section{References}

1. Brester A.A., Bykovskaya A.S. 2015. Sravnitel'no-pravovoy analiz uproshchennogo proizvodstva $\mathrm{v}$ ugolovnom protsesse Rossii i Germanii [Comparative legal analysis of simplified procedure in the criminal procedure in Russia and Germany]. Aktual'nye problemy rossiyskogo prava, 12 (61): 162-170.

2. Butov V.N. 2009. Ekspert v zarubezhnom (kontinental'nom) ugolovnom protsesse [An expert-witness in a foreign (continental) criminal process]. In: Materials of the 2nd Inter. Scientific and Practical Conf. "Theory and practice of forensic examination in modern conditions". Moscow, Prospect, 53-55.

3. Vinogradov A.S. 2014. Sistema dosudebnogo proizvodstva v ugolovnom protsesse Rossii i Germanii [The System of Pretrial Proceedings in the Criminal Procedure in Russia and Germany]. Zhurnal pravovykh i ekonomicheskikh issledovaniy, (3): 32-35.

4. Glotov O.M. 1978. Ekspertiza v sovremennom ugolovnom protsesse FRG [On the examination in the modern criminal trial of FRG]. Izvestiya Vysshikh Uchebnykh Zavedenii. Pravovedenie, (4): 68-74. 
5. Golovenkov P., Ponyatovskaya T. 2015. Ugolovno-pravovoy institut konfiskatsii imushchestva v Germanii i Rossii: sushchnost', vidy i problemy primeneniya [Criminal institution of property confiscation in Germany and Russia: essence, types and problems of application]. In: Germano-Rossiyskaya assotsiatsiya yuristov, Sbornik statey o prave Germanii [Sammelband in russischer Sprache zum aktuellen deutschen Recht]. Hamburg, Deutsch-Russische Juristenvereinigung e.V., 2015, (1): 324-339.

6. Golovenkov P., Spitza N. 2012. Ugolovno-protsessual'nyy kodeks Federativnoy Respubliki Germaniya - Strafprozessordnung (StPO) - Nauchno-prakticheskiy kommentariy i perevod teksta zakona so vstupitel'noy stat'ey professora Khell'manna «Vvedenie v ugolovno-protsessual'noe pravo FRG» [Criminal Procedure Code of the Federal Republic of Germany - Strafprozessordnung (StPO) - Scientific and practical commentary and translation of the text of the law with the introductory article by Professor Hellmann "Introduction to the criminal procedure law of the Federal Republic of Germany"]. Potsdam, Publishing House Potsdam University, 404 p.

7. Grishay I.B. 2003. Dosudebnoe proizvodstvo v ugolovnom protsesse Germanii i Rossii (sravnitel'no-pravovoy analiz) [Pretrial proceedings in the criminal process of Germany and Russia (comparative legal analysis)]: Avtoref. dis. ... kand. yurid. nauk [PhD Thesis Diss. (Law)]. Saint Peterburg, $19 \mathrm{p}$.

8. Derra M. 2015. Verständigung im Strafverfahren. In: Germano-Rossiyskaya assotsiatsiya yuristov, Sbornik statey o prave Germanii [Sammelband in russischer Sprache zum aktuellen deutschen Recht]. Hamburg, Deutsch-Russische Juristenvereinigung e.V., 2017, (2): 284-295. (in German)

9. Ivanova A.V. 2017. Sravnenie proizvodstva sudebnoy ekspertizy po ugolovnym delam v Rossiyskoy Federatsii i Federativnoy Respublike Germaniya [Comparing performance of forensic examination during criminal proceedings in the Russian Federation and the Federal Republic of Germany]. Mezhdunarodnoe ugolovnoe pravo i mezhdunarodnaya yustitsiya, (1): 29-32.

10. Kalinovsky K.B. 2000. Ugolovnyy protsess sovremennykh zarubezhnykh gosudarstv [The criminal process of modern foreign states]. Petrozavodsk, Publishing House of Petrozavodsk State University, $48 \mathrm{p}$.

11. Kashchenko S.G. 2019. Pravovoy status ekspertov v sovremennom germanskom ugolovnoprotsessual'nom prave [The legal status of expert-witnesses in modern German criminal procedure law]. In: Materialy V Mezhdunarodnoy nauchno-prakticheskoy konferentsii «Ugolovnoe proizvodstvo: protsessual'naya teoriya i kriminalisticheskaya praktika» [Materials of the V Inter. Scientific and Practical Conf. "Criminal Proceedings: Procedural Theory and Forensic Practice”]. Simferopol-Alushta, Publishing House of the Crimean Federal University named after V.I. Vernadsky, 43-45.

12. Konovalov S.G. 2017. Germanskiy «sledstvennyy sud'ya» v zerkale rossiyskoy ugolovnoprotsessual'noy nauki: fakty i mify [German "investigating judge” in the mirror of Russian criminal procedure doctrine: facts and myths]. Zakon, (1): 170-181.

13. Konovalov S.G. 2018. Elementy germanskoy modeli dosudebnogo proizvodstva v ugolovnom protsesse postsovetskikh gosudarstv [Elements of the German model of pre-trial proceedings in the criminal process of post-Soviet states]. Avtoreferat dis. ... kand. yurid. nauk [PhD Thesis Diss. (Law)]. Moscow, $22 \mathrm{p}$.

14. Larichev V.V. 2004. Predvaritel'noe rassledovanie prestupleniy v SShA i Germanii [Preliminary investigation of crimes in the USA and Germany]. Avtoreferat dis. ... kand. yurid. nauk [PhD Thesis Diss. (Law)]. Moscow, 24 p.

15. Laty'pov V.S. 2015. K voprosu o protsessual'nom statuse «inykh uchastnikov ugolovnogo sudoproizvodstva» v zakonodatel'stve Germanii [On the issue of the procedural status of "other participants of criminal judicial proceeding" in the legislation of Germany]. Mezhdunarodnoe ugolovnoe pravo i mezhdunarodnaya yustitsiya, (3): 22-25.

16. Lutsik V.V., Voynarovich A.B., Savchenko V.A., Sadovaya T.V., Samarin V.I., Trefilov A.A., Yurchishin D.V. 2018. Ugolovnyy protsess evropeyskikh gosudarstv [Criminal procedure of European states]. Moscow, Prospect, 100-150.

17. Potyomkin I.Yu. 2015. Tseli dokazyvaniya v sisteme printsipov ugolovnogo protsessa Rossii i Germanii: sravnitel'no-pravovoy analiz [Purposes of proof in the system of Russia and Germany criminal procedure principles: a comparative legal analysis]. Vestnik Severo-Vostochnogo gosudarstvennogo universiteta, (23): 71-76.

18. Smirnov A.V. 2001. Sostyazatel'nyy protsess [Adversarial process]. Sant Petersburg, Alpha, $320 \mathrm{p}$. 
19. Stoyko N.G. 2006. Ugolovnyy protsess zapadnykh gosudarstv i Rossii: sravnitel'noe teoretiko-pravoe issledovanie anglo-amerikanskoy i romano-germanskoy pravovykh sistem [The criminal process of Western states and Russia: a comparative theoretical-right study of the Anglo-American and Romano-German legal systems]. Saint Petersburg, Publishing House of Saint Petersburg State University, $264 \mathrm{p}$.

20. Trefilov A.A. 2011. Sistema UPK FRG s prilozheniem v vide perevoda UPK FRG na russkiy yazyk [The system of the Criminal Procedure Code of Germany with the application in the form of a translation of the Criminal Procedure Code of Germany in Russian]. Moscow, Moscow State University, $421 \mathrm{p}$.

21. Filimonov B.A. 1994. Federativnaya Respublika Germaniya. Ugolovno-protsessual'nyy kodeks [Federal Republic of Germany. Criminal Procedure Code]. Moscow, Manuscript, 204 p.

22. Shevtsova L.V. 2018. K voprosu o sootnoshenii ugolovnogo presledovaniya uchastnikov prestupnykh organizatsiy $\mathrm{v}$ Rossii $\mathrm{i}$ stranakh romano-germanskoy sistemy prava [Revisiting the correlation of criminal prosecution of members of criminal organizations in Russia and the countries of Romano-Germanic legal system], Sovremennyy yurist, (1): 75-81.

23. Bošković A., Radović N. 2018. Comparative overview of the preliminary proceedings in the Republic of Serbia, Germany, and Italy. International Journal of Law, Crime and Justice, 52 (March): 47-57.

24. Kirchhofer S. 2017. Die Untersuchungshaft in Südamerika und Deutschland. Eine rechtsvergleichende Analyse. Wiesbaden, Springer Fachmedien, 273 p.

\section{ИНФОРМАЦИЯ ОБ АВТОРАХ}

Лукичев Борис Аркадьевич, кандидат юридических наук, доцент, научный консультант Урало-Сибирской коллегии адвокатов, Екатеринбург, Россия

Алексеев Сергей Геннадьевич, кандидат химических наук, доцент, научный консультант Уральского научно-исследовательского института Всероссийского добровольного пожарного общества, Екатеринбург, Россия

\section{INFORMATION ABOUT THE AUTHORS}

Lukichev B. Arkad'evich, Doctor of Philosophy (Law), Associate Professor, Expert Consultant of Ural-Siberian Bar Association, Yekaterinburg, Russia

Alexeev S. Gennad'evich, Doctor of Philosophy (Chemistry), Associate Professor, Expert Consultant of Ural Research Institute of the All-Russian Voluntary Fire Society, Yekaterinburg, Russia 